\title{
The Postcolonial Paradox in the (Self-)Orientalization of Taiwanese History in Wei Te-Sheng's Action Saga*
}

\author{
Che-ming Yang \\ Department of Foreign Languages and Literature, National Cheng Kung University, Taiwan \\ Email: yang5692@mail.ncku.edu.tw
}

\begin{abstract}
Viewed from a postcolonial angle, this paper intends to examine the paradoxical aspects of the Taiwanese director Wei Te-Sheng's action saga by analyzing both the Orientalization of the Taiwanese aboriginal saga/epic and the literary aesthetics of minor writing/literature that happens to create a resistance literature in this movie. In other words, I plan to examine the problematic aspects-both positive and negative aspects - of Wei's Orientalization of this epic/saga movie. And the main postcolonial literary theories appropriated in this paper are those of Said, Spivak, Bhabha and Deleuze.
\end{abstract}

Index Terms—postcolonial paradox, Seediq, Orientalization, Taiwanese, Japanese

\section{INTRODUCTION}

A Venice film review made by Deborah Young rightly pinpoints the controversial reception of Wei Te-Sheng's action saga (Warriors of the Rainbow: Seediq Bale) ${ }^{1}$ :

Stunning to look at, authentic to a fault and a little tedious to follow for over two and a half hours, the Taiwanese action saga... tells the true story of Taiwan's aboriginal people who were almost wiped out by Japanese colonizers in the 1930s. Their rebellion under the leadership of Chief Mouna Rudo is recounted in a spectacular, almost non-stop sequence of grisly hand-to-hand combat scenes.

Though claiming to retell the historical tragedy (the Wushe Incident), the 1930 uprising against the Japanese colonization led by Mona Rudao, a chief of one of the aboriginal Seediq tribes, Wei has made a few alterations of the historical Wushe Incident in this epic movie when representing the historical massacre so that the heroic narrative could reach an epic scale. There are many positive and negative commentaries on the film at the same time. A descendant of one of the surviving Seediq warriors who participated in this uprising, Dakis Pawan (Kuo Ming-Cheng), who is also a historian and the Seediq dialect consultant of this movie, reminds the audience of the differences between history and the fictional movie, for he discovers there are several dramatic scenes being added to the representation of this tragic event (e.g., the group tattooing of the juvenile warriors). Yet, Dakis also highly values this movie for its recreation of some grandeur moments of the historical event. Given the above-mentioned, we may thus infer that Wei has created a historiographic metafictional "epic" film by reshaping several historical figures and scenes so that the past is revisited to the extent of opening itself "to the present, to prevent it from being conclusive and teleological." ${ }^{2}$

While narrating and representing the exotic Taiwanese aboriginal saga, Wei appropriates the ideas and features of a Western literary genre- "epic," which combines legend/myth and history. From a postcolonial perspective, Wei inevitably puts himself in a dilemma: to be true to the archives of the historical Japanese colonial rule over Taiwanese

\footnotetext{
* In this paper, though basing on Said's concept of Orientalism, my ideas of its derivatives such as Orientalist or Orientalization connote more widely than Said's binary juxtaposition of the East and West. Rather, it connotes the intentional representation of the exotic ethnic or racial or cultural features undertaken either by the colonizer and the colonized elite class. In this movie, though the director Wei Te-Sheng is not a descendant of either the Japanese colonizer or the colonized Seediq, his intentional/artistic representation happen to correspond to Said's concept of the Orientalist project in a colonial context. In addition, Wei, a Taiwanese Han descendant, may be also considered a descendant of the Taiwanese Han colonizers from China. More importantly, Wei as a Taiwanese filmmaker, seems to "commit" the "sin" of doing self-Orientalization of Taiwanese historical event by focusing on the representation of the exotic cultural heritage of the aborigines as well as employing the Western mode of historical writing-the epic tradition.

${ }^{1}$ This is the second feature movie of the Taiwanese movie director Wei Te-Sheng. It has received high recognition and attention. Above all, it was selected as a contender for the nomination for the $84^{\text {th }}$ Academy Awards for the Best Foreign Language Film in 2011 . The main reception by the worldwide audience could be summarized as follows: "Early reaction to the movie has noted both the realism of its violence (which is due to the historical accuracy of its depictions of battle), and its undertone of Taiwanese nationalism"(excerpt from Wikipedia).

${ }^{2}$ See Linda Hutcheon, A Poetics of Postmdoernism, New York: Routledge, 1988, 109-10. Hutcheon argues that "historiographic metafiction is the most typical postmodern fiction, for it blends literature and history in one text while keeping from some critical distance from both of them (the literary and historical texts it refer to). Above all, "The postmodern paradoxes here are complex. The interaction of the historiographic and the metafictional foregrounds the rejection of the claims of both 'authentic' representation and 'inauthentic' copy alike... postmodern fiction suggests that to re-write or to re-present the past in fiction and in history is, in both cases, to pen it up to the present, to prevent it from being conclusive and teleological."
} 
aborigines or to focus on the creation of cinematic dramatic effects by employing some Hollywood cinematic production techniques at the expense of historical truth for appealing to universal audience. Moreover, when representing the exotic scenes Wei is also doing some self-Orientalization of Taiwanese aboriginal culture and history. Above all, Wei declares that he is not narrating the uprising from some traditional historians' perspective. Rather, he intends to revisit the historical tragedy from a "warrior's" or "hunter's" perspective and to arouse some public contemplation on this historical event. As a result, Wei seems to create a counter-narrative that is characteristic of the Deleuzian minor literature. Consequently, from a postcolonial angle, this paper intends to examine the paradoxical aspects of the action saga by analyzing both the Orientalization of the Taiwanese aboriginal saga/epic and the literary aesthetics of minor writing/literature that happens to create a resistance literature in this movie. In other words, I plan to examine the problematic aspects - both positive and negative aspects - of Orientalization of this epic/saga movie. And the main postcolonial literary theories I intend to appropriate are those of Said, Spivak, Bhabha and Deleuze.

\section{REWRITING (Hi)STORIES: ORIENTALIZATION OF TAIWANESE AbORIGINAL SAGA/EPIC}

In terms of the "connections between Orientalism as a body of ideas, beliefs, clichés, or learning about the East, and other schools of thought at large in the culture," Said has singled out two kinds of Orientalism: latent Orientalism and manifest Orientalism. The former is "an almost unconscious (and certainly an untouchable) positivity, while the other is the discursive field of "the various stated views about Oriental society, languages, literature, history, sociology, and so forth" (Said, 1994, p. 205-06). Latent Orientalism often "encouraged a peculiarly (not to say invidiously) male conception of the world" (Said, 1994, p. 207). In this movie Warriors of the Rainbow, women happen to be marginalized and represented as obedient and silent subjects in both the colonial discourse and the aboriginal epic/saga, as Said puts it, "women are usually the creatures of a male power-fantasy. They express unlimited sensuality, they are more or less stupid, and above all they are willing" (Said, 1994, p. 207). The women are thus silenced in the movie. They seldom speak for themselves. Instead, the male narrative voices speak for them. Women in this movie commit suicide together by hanging themselves on the trees in order not to become a burden to their husbands and sons in their fighting against the Japanese colonizer. Yet, according to some Japanese archives of the Wushe Incident, most women and children just surrendered (without the description of their suicide) to the Japanese army in charge of suppressing this uprising (Wushe Incident: An Translation of the Japanese Archives, Vol. 2, 84). This is a rewriting/Orientalization of the historical uprising. Coincidently, these women who kill themselves, just like suttee (the widow who sacrifices herself in the funeral of the dead husband) that Spivak depicts in "Can the Subaltern Speak?", are the victims of a double displacement (class and gender). Here, paradoxically, race is not a persuasive factor in the postcolonial context.

On the other hand, the male Seediq warriors are highlighted as extremely warriors fighting for their ideals (to enter the ultimate or eternal glorious battle field over the rainbow) and national/racial identity and dignity. In this movie, the male warriors sing some ancient heroic songs, especially the protagonist, Mona Rudao. He often isolates himself in meditation on the ancestral voice for directions about how to fight against the Japanese while communicating with the ancestral spirit. All the Seediq ancestral voice or spirit in this movie is male. The Seediq ancient spirit seems to be always male and eternal, brooding over the natural surroundings of the Seediq tribal villages and wilderness. The protagonist frequently turns to the ancestral spirit for inspiration, just like the ancient Greeks who often seek instruction from the oracles of sun-god Apollo.

Given the above, the director Wei seems to create a Orientalized Taiwanese epic out of the saga of the Taiwanese aboriginal tribe-Seediqs - so that this movie would look appealing to the universal audience. Originally a Western literary tradition (genre), epic nowadays has gained universal prestige and recognition. To create an epic, based on the Western epic tradition, first of all, the epic poet has to find a "proper" hero whose heroic deeds are connected with the collective fate of his people (with national significance). In the movie, the protagonist, Mona Rudao is almost deified so that his heroic deeds are celebrated to the extent of national historical significance. As a result, Mona Rudao becomes the tribal hero whose charisma and heroic deeds are singled out and canonized as the Western epic tradition goes. Therefore, an Oriental tribal saga is thus Orientalized by the Western literary modes of representation of the national heroes whose fate is equal to or bound with the national history, be it factual or somewhat fictional.

To further examine how the Taiwanese saga is Orientalized by Wei's appropriation and representation of the epic tradition in this movie, we should closely re-examine the variety and definition of Western epic tradition. Many literary encyclopedias or handbooks like Merriam-Webster's Reader's Handbook (1997) define epic as “[a] long narrative poem in an elevated style that celebrates heroic achievement and treats themes of historical, national, religious, or legendary significance" (Doherty and Cornog, 1997, p. 165). Besides, we may also distinguish "primary (also called traditional or classical) and "secondary (or literary) epics. Primary epic was "shaped from the legends and traditions of a heroic age and part of the oral tradition of literature, while secondary epic was "written down from the beginning and was self-consciously produced by sophisticated poets who adapted aspects of traditional epic for specific literary and ideological purposes" (Doherty and Cornog, 1997, p. 165). Viewed from the categorization of epic, we can see that "Homer's Iliad and Odyssey are primary epics; Virgil's Aeneid and John Milton's Paradise Lost are secondary epics" (Doherty and Cornog, 1997, p. 165). Given the above-mentioned, we may conclude that Wei's Warriors of the Rainbow: Seediq Bale is mostly following the Western secondary epic tradition, for it mainly re-writes several aspects of the traditional Seediq saga for "specific literary (artistic) and ideological purposes." 
Originally part of a folk saga that has been orally handed down to the Seediq descendants, Mona Rudao's heroic deeds and his involvement with the Wushe Incident are thus re-written in Wei's historiographic metafictional epic movie. Though the Wushe Incident has been recorded in the historical archives of both the Taiwanese Han people and the Japanese, many episodes of Mona Rudao and his fellow warriors have been an oral heritage preserved by the elderly Seediq warriors who survived this catastrophe. Dakis, in his painstaking work, something like a documentary book-Seediq Bale (literally means real truth)—records the Seediq cultural and historical heritage and makes a comparative study of the various perspectives of the Seediq elderly men and the movie staff. Dakis points out that he had spent about twenty years doing field studies about the tribal history and cultural tradition as well as the Wushe Incident by interviewing carefully the Seediq chiefs and the elderly Seediqs, especially those survivors of the Wushe Incident. From this work, we can see that Mona Rudao's role as a Seediq national hero is disputed. Moreover, he did not participate in all the major battles against the Japanese (Kuo, 2011, p. 12).

Just like Zhou Wan-yao (who wrote the preface for Dakis's “documentary" book), a professor of history at National Taiwan University has indicated, Dakis realizes that there are several episodes or details in this movie that deviate, some of them seriously, from the historical truth. Yet, Dakis still recognizes the endeavors that Wei has made in making some alterations of the Wushe Incident for creating some cinematic or dramatic effects in this movie. For example, to foreground the wrath or confrontation between two heroic figures, just like ancient Greek or Roman epics, Wei singles out a scene in which Mona Rudao challenges his key opponent, Temu Walis, by saying "I'd never allow you to grow up," though this statement is strongly against the Seediq ethics (Kuo 2011). This alteration seems to duplicate the wrath of Achilles and the tension between him and Agamemnon in Homer's Iliad. Above all, in this movie, Wei just focuses on the dramatization of the charisma and bravery of the epic hero Mona Rudao by neglecting or diminishing the description of the courageous acts of other warriors, such as Mona's oldest and second sons and the other tribal chiefs who also participated in this uprising.

Nevertheless, despite the above-mentioned intentional historiographic metafictional writing of the uprising, Wei has created some counter-narrative of the minority (Seediqs) - minor writing — in reaction to/against the major (majoritarian) writing of the Wushe Incident, which is mainly from the colonizers' perspective (the Han people in Taiwan and the Japanese alike). Wei, in several interviews, emphasizes that he tries to represent the historical incident from a Seediq warrior's point of view. As a result, he not only defies the canonized historical archives preserved by both the Hans and the Japanese, but also re-writes some of the memories of the surviving warriors. And the above-mentioned happens to coincide with Deleuzian micropolitics of minor literature/writing.

\section{TOWARD A MinORITARIAN COUNTER-NARRATIVE OF THE SUbALTERN—RESISTANCE LiteratURE IN WARRIORS OF THE RAINBOW: SEEDIQ BALE}

We all know that history, just like other discursive texts, is a kind of human constructs, and thus is never transparent and free from human mediation. Thus, instead of closely basing on the surviving warriors' memories or perspectives, Wei decides to re-write the history of the Wushe Incident according to his strategic needs of arousing the long-neglected historical incident. Though some historians like Dakis challenged his representation of this historical event, Wei chooses to establish his postcolonial aesthetics of re-writing history without being subjected to the majoritarian historical writing by either the Japanese or the Han people (a historical perspective as oppressive as the Oedipal mechanism of Freudian/Lacanian psychoanalysis), as Deleuze puts it:

To write is not to recount one's memories and travels, one's loves and griefs, one's dreams and fantasies. It is the same thing to sin through an excess of reality as through an excess of the imagination. In both cases it is the eternal daddy-mommy, an Oedipal structure that is projected onto the real or introjected into the imaginary. In this infantile conception of literature, what we seek at the end of the voyage, or at the heart of a dream, is a father [emphasis added]. (Deleuze, 1997, p. 2)

To highlight the fact that all writing (including historical texts) is saturated with human ideological mediation, Wei makes some alterations, as Deleuze puts it: "There is no literature without fabulation" (Deleuze, 1997, p. 3).

To dramatize the lines of flight (becoming) of the Seediqs, Wei achieves a minor writing. This writing has nothing to do with the number of the people it aims to appeal to or the identity of the writer/filmmaker who undergoes the becoming of minority. Wei, just like Kafka (for central Europe) and Melville (for America), presents "literature as the collective enunciation of a minor people, or of all minor peoples, who find their expression only in and through the writer [emphasis added]" (Deleuze, 1997, p. 4). In other words, the long distorted or marginalized history of the Seediqs has been reclaimed by Wei in this movie as a minor writing of impossibility - "the impossibility of not writing, the impossibility of writing in Chinese/ Japanese, the impossibility of writing otherwise." 3 Wei has successfully reconstructed "the story not to pass on" of the Seediq victims in the Wushe Incident, even though most of the warriors are dead and the Seediq descendants and many outsiders nowadays neglect this historical tragedy of the Seediqs, Retelling the hi(story) from the Seediq warriors' perspective, Wei successfully "invents a people who are missing" in

\footnotetext{
3 This is an adapted quote from Kafka: Toward a Minor Literature (1986), in which Deleuze and Guattari depicts the awkward situation of the Jews living in Prague who deterritorializes the major language - German. Thus, Kafka's minor writing is something impossible: "the impossibility of not writing, the impossibility of writing in Chinese/ Japanese, the impossibility of writing otherwise" (16).
} 
this minor writing to the extent of arousing the Taiwanese as well as the worldwide audience to revisit and retrieve this historical tragedy by challenging the existent historical archives of either the Japanese or the Han peoples in Taiwan. Just like "Thomas Wolfe "inscribes all of America in writing insofar as it can be found in the experience of a single man," Wei's minor writing does not create "a people called upon to dominate the world. It is a minor people, eternally minor, taken up in a becoming-revolutionary" (Deleuze, 1997, p. 4). This is the political function of modern literature or cinema like Warriors of the Rainbow, as Daniel Smith explains:

If modern political literature and cinema can play a role in the constitution of minorities, it is because they are no longer undertaken on the basis of a "people" who are already there, awaiting their becoming conscious and the possibility of revolution. Rather they are constituted on a seot fo impossibilities in which the people are missing, in which the only consciousness is the consciousness of violence... For Deleuze, this is what constitutes the new object of a political literature or cinema: the intolerable, that is, a lived actuality that at the same time testifies to the impossibility of living in such conditions. ("Introduction," Deleuze 1997: xliii)

In addition, by means of depicting the warriors' return to the Absolute/Ultimate Realm of eternity, Wei happens to correspond to Deleuze's idea of becoming. Portraying the process of the warriors' return to the transcendental realm, Wei is undertaking an act of writing as becoming. In Deleuzian terms, writing is an act or a question of becoming, always incomplete, always in the midst of being formed, and goes beyond any livable or lived experience... Writing is inseparable from becoming: in writing, one becomes-woman, becomes-animal or vegetable, becomes-molecule to the point of becoming-imperceptible. (Deleuze, 1997, p. 1)

In the movie, Wei explores the transcendental aspects of the warriors' idealized refuge of eternity - the battle field for the courageous warriors over the rainbow, guarded by their ancestral spirit. The warriors' lifelong objective is to re-unite with their ancestral spirit, which is often referred to as a transcendental impersonal Central Divinity of Nature.

In the end of the movie, all the dead warriors are marching over the cloud toward the rainbow. Wei seems to emphasize the process of becoming-imperceptible with the idealized rainbow of the warriors. The rainbow has become a symbol of heaven where the courageous warriors can take refuge in and a token of comfort and reward for their torture and sacrifice. It is also a spiritual realm of purity. In other words, in Deleuzian terms, by fighting courageously against the Japanese colonial oppressive rule, the Seediq warriors seem to become a "war-machine," which is "irreducible to the State apparatus, to be outside its sovereignty and prior to its law" (Deleuze, 1987, p.352), undertaking a jihad, a holy war against the enemy, because the Japanese imperialist inflict blasphemy upon their ancestral spirit by depriving them of the link with their cultural heritage (e.g., facial tattoo and hunting). To be more specific, the rainbow is also a symbol of the Sublime, a desired refuge of eternity and glory for every Seediq warrior (though the women are marginalized here). The warriors are taking flight, becoming in order to reach the desired realm - the rainbow, just like Harry, who is the protagonist in one of Hemingway's well-known short stories "The Snows of Kilimanjaro," in which Harry shows "great spiritual attachment to a mountain/peak that is a symbol of purity and escape" (Yang, 2010, p. 44). We may interpret the Seediq warriors' lines of flight toward the rainbow as a kind of act of escape or refuge away from the Japanese oppression.

Paradoxically, this becoming-imperceptible of the warriors, namely their lines of flight, is achieved through becoming-savage. As Mona Rudao has proudly declared when he decides to fight against the Japanese oppression because the Japanese colonial regime has always considered the Seediqs as savage:

If civilization means humiliation and slavery, I would have them see the pride of the savages!!

For Deleuze, becoming-minor, becoming-animal or barbarian is always a minor writing, for it deviates from the major discourse and social modes that imposed on the individual who seeks lines of flight (deterritorialization). In repudiating the majoritarian ideology of the Japanese colonizers who consider the Seediqs as "savages," Wei tries to have Mona Rudao deterritorialize the Japanese majoritarian colonial discourse by becoming-savage.

\section{The Postcolonial Paradox in the Orientalization of Taiwanese History}

From the above analysis, we can detect that by Orientalizing the Taiwanese aboriginal saga, Wei has created both positive and negative effect. The former is his dramatic representation of the exotic features of the Seediq cultural heritage and the Wushe Incident according to the Western modes of representation (epic tradition), values and behavior; whereas the latter, the minoritarian or minor writing in reaction to/against the majoritarian or dominant historical writing. Nevertheless, even though Wei tries hard to reclaim the identity and dignity of the Seediqs by re-writing this tribal saga/epic, he has brought about many effects in a postcolonial context that he may not notice. We can hardly judge whether Wei's Orientalization is positive or negative for the colonized and marginalized minority-Seediqs.

Moreover, though there are both positive and negative aspects of Wei's Orientatlization of Taiwanese history, yet, according to Homi K. Bhabha's postcolonial perspective, there are also some paradoxical aspects in the colonial discourse (Orientatlization project), for it is never absolute and complete:

The objective of colonial discourse is to construe the colonized as a population of degenerate types on the basis of racial origin, in order to justify conquest and to establish systems of administration and instruction... colonial discourse produces the colonized as a social reality which is at once an 'other' and yet entirely knowable and visible.... It [colonial discourse] employs a system of representation, a regime of truth, that is structurally similar to realism. And it is in order to intervene within that system of representation that Edward Said proposes a semiotic of 'Orientalist' power, examining 
the varied European discourses which constitute 'the Orient' as a unified racial, geographical, political and cultural zone of the world. (Said, 1994, p. 70-71)

By reviewing Said's concept of Orientalism, Bhabha pinpoints the paradoxical aspects of the discourse of colonialism with the idea of ambivalence, which means the contradictory attitude of the colonizer toward the colonized, because in the colonial texts, the colonized are simultaneously "the signal points of identification and alienation, scenes of fear and desire" (Said, 1994, p. 72). Likewise, in the movie, on the one hand, though the Japanese name and treat the Seediqs as the" other" of the Japanese - "savages"; yet, on the other hand, the Japanese colonizers attempt to domesticate the colonized Seediqs and abolish their radical 'otherness,' bringing them inside the Japanese understanding through "the Orientalist project of constructing knowledge about them" (McLeod, 2000, p. 53). As a result, the objective of colonial discourse is never complete and absolute.

For example, the two Seediq young men who work for the Japanese police at the Wushe area are a good illustration of the ambivalence in the Japanese colonial rule over the Seediqs. Both of them have adopted a Japanese name respectively, Hanaoka Ichiro and Hanaoka Niro (花崗一郎與花崗二郎). In this movie, Wei takes pains to dramatize their inner struggle for the dilemma: to recognize the Japanese civilized colonization of the primitive Seediqs or to join their fellow Seediq warriors in this uprising. Both of them are torn between their inner struggles. Nevertheless, according to Dakis's investigation (Kuo, 2011, p. 18), these two Seediq young men are supposed to be "the accomplices" of the Japanese police that oppress and suppress the aborigines and the traitors to the Seediqs in the eyes of the Seediqs. How could they be informed of and participate in the Seediq warriors' uprising against the Japanese? Here, we may infer that Wei intends to have these "domesticated" Seediq elite young men raise questions and dramatize the dilemma of choosing between civilization and nationalism (national/cultural identity and dignity). Therefore, this episode, is supposed to be a minoritarian writing of the Wushe Incident in reaction to/against the majoritarian historical perspective that takes it for granted that all the colonized Seediqs are strongly against the Japanese colonial rule. It demonstrates the political function/destiny of minor writing through an invention of "a people who are missing," as Daniel W. Smith puts it,

Hence the belief that literature or even the cinema...could become an art of the masses, a supremely revolutionary or democratic art.... If art was to find a political task, Deleuze argues, it would have to be on a new basis, that is, on the basis of this very fragmentation and breakup: not hat of addressing an already existing people, but of contributing to the invention of a people who are missing. (xli-xlii)

\section{CONCLUSION}

In Warriors of the Rainbow: Seediq Bale, Wei, though intentionally creates some Orientalization of the Taiwanese aboriginal saga in parallel with the Western Orientalist project of the East, he successfully foregrounds several problematic aspects of this long-neglected historical tragedy. Wei seems to blur the borderline between history (reality) and fiction (cinema). Though he may be accused of intentionally representing some exotic aboriginal elements for creating universal appeal, Wei has successfully aroused the interest and awareness of universal audience for "intolerable" historical moment in Taiwanese history and the need to revisit it. The audience tends to treat all the scenes and events represented in the cinema as historical truth by Wei's vivid and subtle cinematic narration.

\section{REFERENCES}

[1] Bhabha, Homi K. (1994). The Location of Culture. London: Routledge.

[2] Deleuze, Gilles. (1997). Essays Critical and Clinical. Trans. Daniel W. Smith and Michael. A. Greco. Minneapolis: U of Minnesota P.

[3] Deleuze, Gilles, and Felix Guattari. (1986). Kafka: Toward a Minor Literature. Trans. Dana Polan. Minneapolis: U of Minnesota P.

[4] Deleuze, Gilles, and Felix Guattari. (1992). A Thousand Plateaus: Capitalism and Schizophrenia. London: Athlone.

[5] Doherty, Kathleen M. and Mary W. Cornog, eds. (1977). Merriam-Webster's Reader's Handbook. Springfield: Merriam-Webster.

[6] Haluyama, Metotetsu. (2010). The Wushe Incident: A Translation of the Japanese Archives. 2 Vols. Taipei: National History Museum.

[7] Hutcheon, Linda. (1988). A Poetics of Postmodernism: History, Theory, Fiction. New York: Routledge.

[8] Kuo, Ming-Cheng (Dakis Pawan). (2011). Seediq Bale. Taipei: Yuan-liu.

[9] Mcleod, John. (2000). Beginning Postcolonialism. Manchester: Manchester UP.

[10] Rossington, Michael. (1995). "Homi, K. Bhabha." The A-Z Guide to Modern Literary and Cultural Theorists. Ed., Stuart Sim. London: Prentice Hall, 49-53.

[11] Said, Edward. (1994). Orientalism. New York: Vintage.

[12] Smith, Daniel W. (1997). Introduction. Essays Critical and Clinical. Trans. Daniel W. Smith and Michael. A. Greco. Minneapolis: U of Minnesota P.

[13] Spivak, Gayatri C. (1994). "Can the Subaltern Speak?" Coloncial Discourse and Post-colonial Theory. Ed. Patrick Williams

\footnotetext{
${ }^{4}$ See Daniel Smith's “Introduction" to Deleuze's Essays Critical and Clinical (1997). For Deleuze, the intolerable is "a lived actuality that at the same time testifies to the impossibility of living in such conditions," namely, the "new object of a political literature of cinema" (xliii).
} 
and Laura Chrisman. New York: Columbia UP.

[14] Yang, Che-ming. (2010). "The Paradox of Transgressing Sexual Identities: Mapping the Micropolitics of Sexualities/Subjectivities in Ang Lee's Films." Asian Culture and History Vol. 2.1, 41-47.

[15] Young, Deborah. "Warriors of the Rainbow: Seediq Bale." The Hollywood Reporter. http://www.hollywoodreporter.com/review/warriors-rainbow-seediq-bale-venice-230239. February 12, 2012.

[16] “Warriors of the Rainbow: Seediq Bale." Wikipedia. http://en.wikipedia.org/wiki/Warriors_of_the_Rainbow:_Seediq_Bale

Che-ming Yang was born in 1967 in Taichung, Taiwan. He was conferred in June 1999 the degree of PhD in English and American literature by the Department of English, National Taiwan Normal University, Taipei, Taiwan. His major study field then was contemporary literary theories with a focus on postmodern historiographic metafiction. But most recently, his research interests have shifted to cultural studies that encompass a Deleuzian literary aesthetics, postcolonial/postmodern literary theories and mass media, and a comparative study of Western philosophy and Buddhism.

He has been teaching English and Western literature at several universities in Taiwan since 1994. In 1994, he won the Fulbright research grant for "Contemporary American Literature" and went to the United States for a six-week study at Northern Illinois University. Currently, he is an associate professor and chair at the Department of Foreign Languages and Literature, National Cheng Kung University, Taiwan.

In addition, he serves as an editor for Arts and Social Sciences Journal, Aston Journals. 